\title{
PETR SKALNÍK'S COLLECTION IN THE NÁPRSTEK MUSEUM
}

\author{
Gabriela Jungová ${ }^{1}$ - Stanislav Krupař
}

\begin{abstract}
Petr Skalník is a renowned Czech social anthropologist and Africanist. During his studies in the former Soviet Union, he visited Tuva where he assembled a collection of material culture that represents various everyday occupations of cattle herders, as well as ritual and leisure activities. After more than 50 years of its acquisition, the collection, now curated by the Náprstek Museum in Prague, is finally published including a summary of circumstances under which Skalník worked.
\end{abstract}

KEYWORDS: Petr Skalník - Tuva - material culture

\section{Introduction}

The Náprstek Museum of Asian, African and American Cultures cares for a collection of over 100 objects from Tuva assembled by Petr Skalník in 1966. Several items from the collection were on display in 1977-2002 in the Liběchov Chateau's long-term exhibition of Asian cultures. Most of the objects were then displayed on a temporary exhibition Doma na Sibiri (At Home in Siberia) in 2020-2021. Besides these two projects and their respective catalogues ${ }^{2}$ that feature a limited number of objects, Skalník's Tuvan collection of the Náprstek Museum remained unpublished and thus virtually unknown.

\section{Petr Skalník and Tuva}

Petr Skalnik ( $\left.{ }^{*} 1945\right)$ is a Czech social anthropologist and Africanist. As a scholarship student, he spent the years 1963-1967 at the Leningrad State University (now Saint Petersburg State University), where he received the opportunity to participate in the Tuvan Archaeological-Ethnographic Expedition in the summer of 1966 under the supervision of Alexander Danilovich Grach (1928-1981). During this stay in Tuva (then the Tuva Autonomous Soviet Socialist Republic, part of USSR, today the Republic of Tuva, part of the Russian Federation), Skalník met the local people and purchased objects of everyday use with the intention of documenting the contemporary material culture. He collected among the settled rural population that lived in wooden houses or, less commonly, in stationary yurts. Most of the items had been already out of use by the time Skalník purchased them; the locals however explained and, in some cases, demonstrated their purpose. According to Skalník, the price paid for each item should

1 Contact: Gabriela Jungová, National Museum - Náprstek Museum of Asian, African and American Cultures, Prague, Czech Republic; e-mail: gabriela.jungova@nm.cz. This work was financially supported by Ministry of Culture of the Czech Republic (DKRVO 2019-2023/19.II.b, National Museum, 00023272).

2 Asijské kultury 1981; Jungová 2020.

This work is licensed under the Creative Commons Attribution-Noncommercial-No Devivs 3.0 License 
have allowed for the covering of expenses for the purchase of a new product of the same type. In total, Skalník estimated to have spent around 50 RUB for the entire collection. ${ }^{3}$ The assemblage of 108 objects was delivered to the Náprstek Museum in 1967 and was inscribed into evidence under inventory numbers A5201-A5300 and A5451-A5458. The collector himself wrote the evidence cards in January and April 1968, and thus each object has a detailed description, in most cases including its name in Tuvan, the site of acquisition, and approximate dating.

\section{The Collection}

The objects were acquired in or come from Central Tuva, namely the Chaa-Kholsky and Ulug-Khemsky kozhuuns ${ }^{4}$ [Fig. 1], and they represent items of everyday use of non-urban pastoralist population. They include (1) kitchenware, (2) smaller pieces of furniture and other household utensils, (3) equipment for horse riding, (4) tending the herds of cattle, (5) hunting, (6) tools for leatherwork and (7) processing of wool, (8) needs for land cultivation and growing crops, (9) one ritual object, and (10) various other items. Both for practical reasons and for their current unavailability, some types of objects are not represented at all, e.g., large pieces of furniture or clothing, besides several samples of odd shoes. The collection also only contains a single object related to ritual or spiritual life. The collector himself states that he purchased the objects selectively, trying to document as many aspects of daily life as possible. Activities and types of objects that are not represented were omitted either because the related objects were not used, or their owners were not willing to part with them.

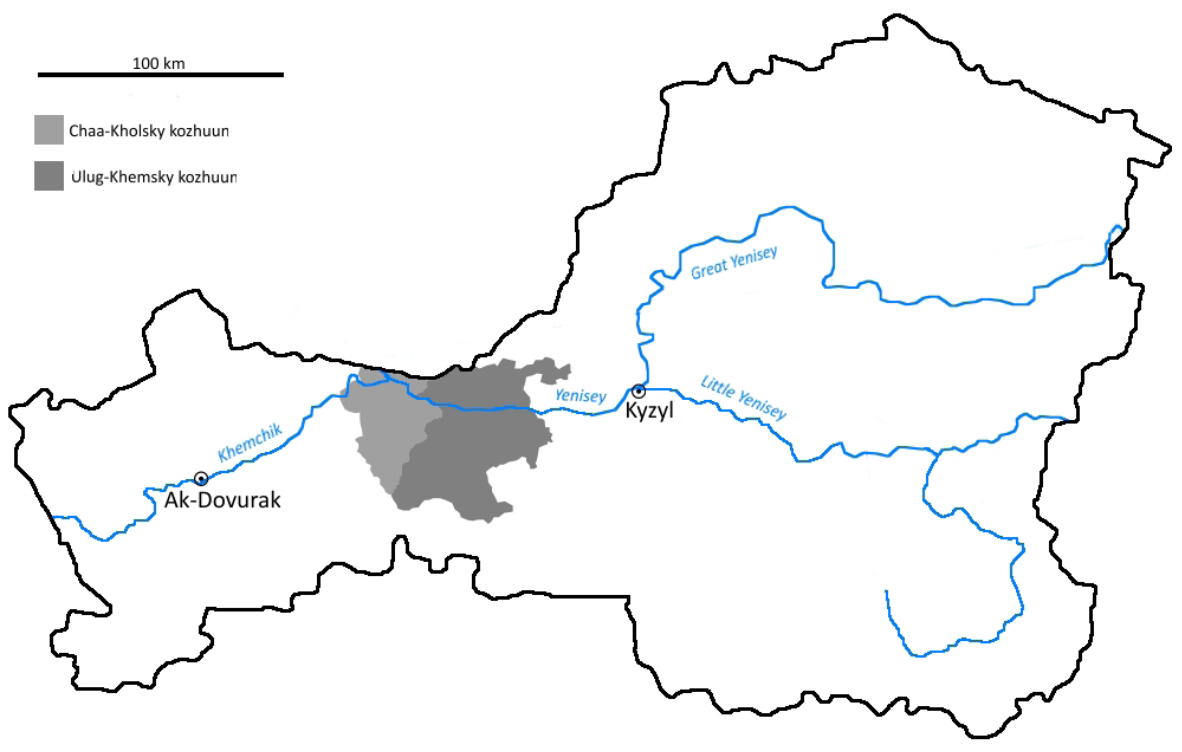

Fig. 1. Map of Tuva with highlighted regions where Skalník conducted his research (Illustration: Gabriela Jungová).

3 Petr Skalnik, personal and e-mail communication; documents in the archive of the donors, file Petr Skalník, letter from 8 August 1966.

4 Tuva is currently divided into 17 administrative units called kozhuиn (кожуун) that are analogous to districts (район) in other parts of the Russian Federation. 


\section{Kitchenware [Pl. 1]}

Kitchenware forms the largest group among the objects assembled by Skalnik and features jars, jugs, troughs, mortars and pestles, bowls, or ladles. These represent a wide range of activities related to storing, processing, and serving food or groceries. The majority of the items are made of poplar wood, as it was widely available in the country and easy to work with. ${ }^{5}$ Other used materials are metal for a tea mortar and a hook, stone for a pestle, rags for a stirring tool, and stoneware. The last material is represented by a single vessel, most likely imported from China. A leather crescent-shaped flask is richly decorated with embossed patterns. The flask served for keeping fermented sour milk khoitpak (хойтпак) or milk spirit araga (арага) and was made in various sizes. Some of the objects represented in the collection are still common in Tuvan households; this is mostly true for wooden troughs that can be used for storing or winnowing grain, kneading dough, storing chunks of meat etc. [Fig. 2]. Other types of kitchenware, however, became obsolete as they were replaced by materials such as plastic, metal, and glass ware (wooden vessels), or the products of their use became readily available in stores (mortars for grinding tea or grain).

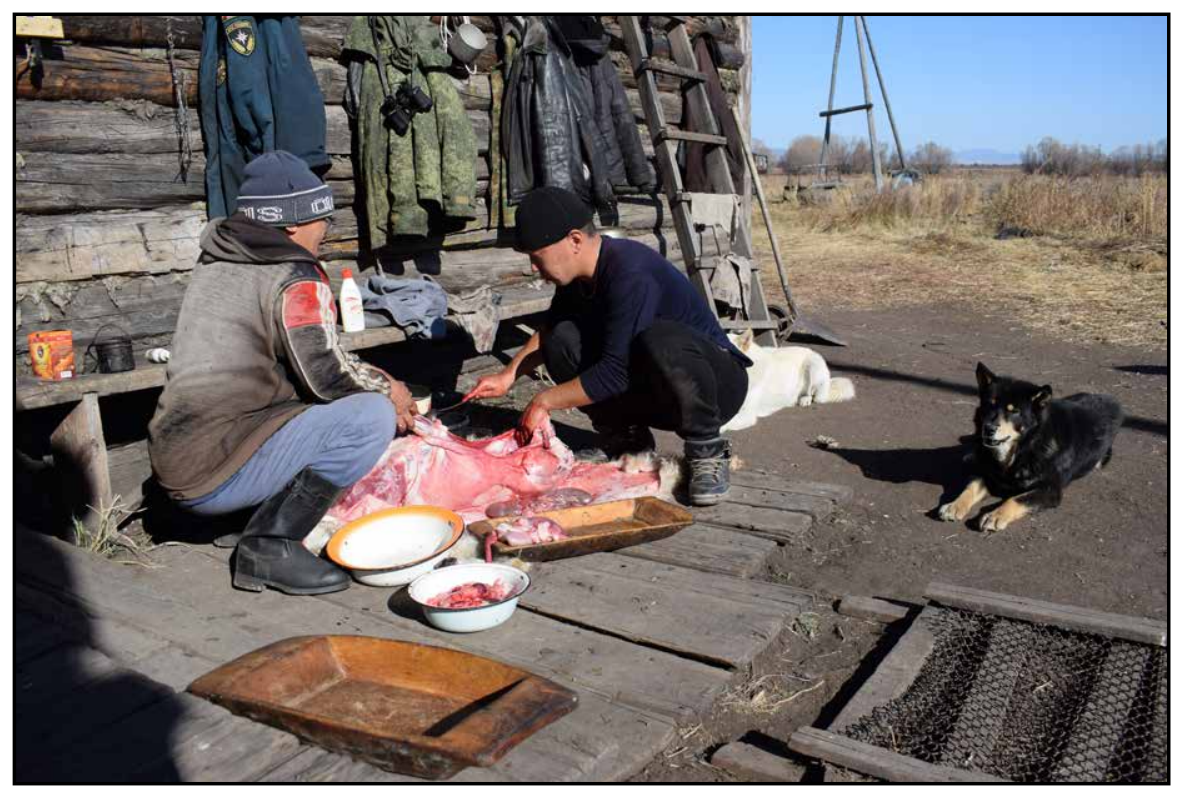

Fig. 2. Wooden troughs used during butchering of a ram. Piy-Khemskiy kozhuun, 2019

(Photo: Gabriela Jungová).

\section{Household needs [Pl. 2]}

This category comprises a wide range of objects that formed the interior equipment or were used in everyday activities related to the care for the household in general. The assemblage is, sadly, not fully representative as some

5 Vainshtein 2009, p. 208. 
types of objects are missing. This mainly includes large pieces of furniture such as beds or tables. According to Skalník, they were not available for sale ${ }^{6}$ but practical concerns including the question of shipment should also be considered. Interior equipment includes painted wooden chests and leather bags for storage, two iron tripods for cauldrons, and small brooms for sweeping and cleaning the cauldrons. The collection also contains three steel padlocks.

\section{Equestrian needs [Pls. 3-4]}

Horses have had an exceptional status in the Tuvan pastoralist culture and still retain it today. They were valued as means of transportation, for their endurance in harsh conditions and for providing materials such as hair, leather, and meat. Horses were even spared working tasks that were considered 'ungrateful' for them, such as ploughing or pulling a cart ${ }^{7}$ and, even though milking was generally exclusively women's work, mares (and camels) were also milked by men. ${ }^{8}$ The high regard is clearly reflected in the omnipresence of horse symbolism: horses are depicted on musical instruments and other objects both of everyday and ritual use, ${ }^{9}$ they are praised in folk songs and stories, even shamanic drums are compared to horses in the sense that they are the shaman's means of transport to the other worlds. It comes as no surprise, then, that equipment for riding and tending the horses did not escape Skalnik's attention, who gained pieces of harness such as bit mouthpieces, a leather strap, and a wooden saddle. The equipment further includes a large saddle bag, horseshoes, stirrups, and horse brasses, i.e., small metal button-like plaques that were used to decorate the harness. Whips were used to direct the horses; of the two present in the collection, one features a lash made of a V-belt, and thus represents an interesting example of reuse of modern materials. The last item in this category is a pair of leather cuffs used to immobilize the horse when necessary.

\section{Herding needs [Pl. 5]}

Tuvan pastoralists are strongly dependent on their herds and flocks that provide them with essential food and raw materials. Their detailed knowledge of the animals is, among others, visible in specific nomenclature based on the sex and age of each head. ${ }^{10}$ Needs for the care of the herds are in the collection, however, only represented by two wooden flaps that served as anti-suckling devices. These were inserted into perforated noses of calves, which prevented them from nursing, but permitted grazing and drinking water. This allowed weaning of the calves without their premature separation from their mothers.

\section{Hunting needs [Pl. 6]}

Hunting played an important role in Tuvans' subsistence and economy, not only as a source of meat, but also pelts that were traded or paid as a tribute. The original bow and arrow were gradually replaced by muzzle-loading muskets and

Даржа 2009, p. 205.

8 Vainshtein 2009, p. 66.

9 See the libation spoon A5294 in the section 9. Ritual objects. 
rifles which is reflected in the shift of terms for the bullet (ok [ок] - originally arrowhead), and the set of the pouch for gunpowder, measure, and the bulletpouch (saadak [саадак] - originally quiver). ${ }^{11}$ The collection features one gunpowder pouch made of soft leather with a neck formed by a brass cartridge case, and a separate percussion lock. Based on its size, it can be assumed that it was a part of a long gun. The third item was a pair of leather bags that were strapped to the saddle. Although these bags were also used by pastoralists, they were most commonly employed by hunters. No implements for fishing were collected.

\section{Leatherwork [Pls. 7-9]}

The collection contains seven objects related to working and decorating leather. Three odd children's boots are also included in this category, as they are a sample of leatherwork, rather than a representation of footwear.

Processing raw hides was a lengthy process that required various tools and involved a number of steps, depending on the kind of hide. ${ }^{12}$ The tools in the collection document only some of the procedures and include three tools for softening of the hide, a decoration stencil consisting of a wooden board with a carved ornament on one side that was transferred on the leather by pressing, an awl, and a felt thimble. A last made of wooden plank was used for shoemaking.

\section{Needs for wool processing [Pl. 10]}

Processing of wool was essential as it provided felt, thread, and yarn, but since many steps only used simple tools such as wooden logs and sticks ${ }^{13}$, there are only a few examples of specialized needs. These include wooden suspended spindles for spinning yarn, and iron scissors with handles covered with wool; they were used for cutting final products such as felt. Shearing blades are not a part of the collection. Two samples of felt and a small felt bag with geometric stitching represent the material that was used for clothing, mats and blankets, storage bags, and yurt coverings.

\section{Needs for land cultivation [P1. 11]}

Although the flesh and milk of the cattle formed the basis of Tuvans' diet, many families in the Khemchik and Ulug-khem valleys, including the nomadic ones, also cultivated land to gain plant crops. ${ }^{14}$ These activities are documented in Skalník's collection by two iron tips of a ploughing instrument, whether from a spade or an ard, ${ }^{15}$ and a sickle for harvesting.

\section{Ritual objects [Pl. 12]}

The ritual and spiritual life of the Tuvans is represented by a single item. Tos karak, a nine-eyed ritual spoon, is still commonly used for the libation of tea and milk both privately within informal everyday spiritual practice, and as

11 Даржа 2009, p. 98; Левин and Потапов 1956, p. 434; Vainshtein 2009, pp. 168, 169-170.

12 Vainshtein 2009, pp. 212-217.

13 Даржа 2009, pp. 138-144; Vainshtein 2009 (1980), pp. 209-212.

14 Vainshtein 2009, pp. 147-160.

15 Cf. Vainshtein 2009, p. 155, Fig. 3. 
part of shamanic rituals [Fig. 3]. The example collected by Skalník is made of a single piece of wood with dark brown patina. The spoon is long, with double curvature; the bowl is rectangular, shallow pits represent the nine 'eyes'. It is richly decorated with carvings, featuring from the bowl to the end: two steps towards the higher universe; a series of four geometric knots representing a simplified endless knot (өлчей удазыны); one left-facing swastika (кас демдек) in low relief and one right-facing swastika in high-relief; a dragon's head and a horse head facing away from each other, the latter being the very end of the handle. ${ }^{16}$

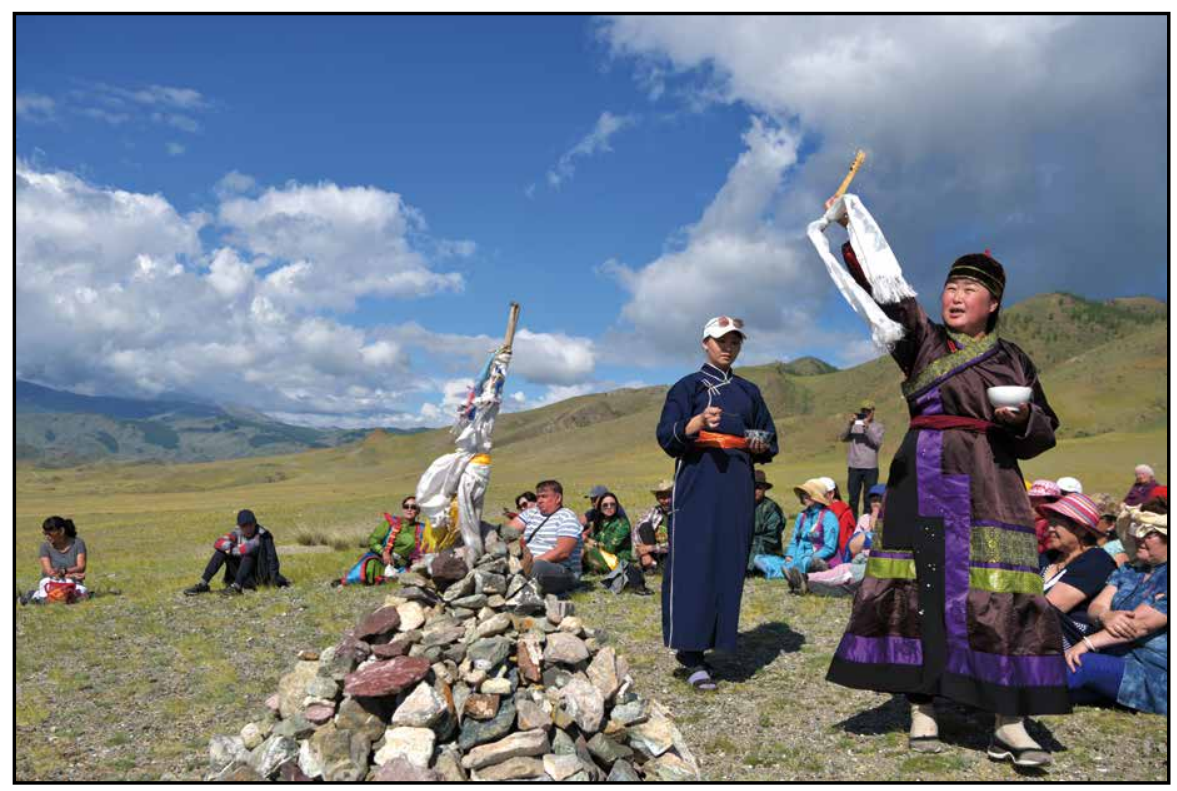

Fig. 3. Libation of milk with ceremonial spoon during Buddhist consecration of a sacred place ovaa. Bay-Tayginsky kozhuun, 2019. (Photo: Stanislav Krupař).

\section{Miscellaneous [Pls. 13-14]}

The last category is wide and diverse as it contains objects that for various reasons did not fit into any of the aforementioned categories. However, this certainly does not mean that they are in any sense less important. A knife, for instance, was used in a range of daily activities and thus formed an essential piece of equipment of every Tuvan. Although used both by men and women, the knife as a symbol is closely connected to masculinity among the Tuvans. Indeed, both samples - a knife with a wooden sheath and a separate sheath - collected by Skalnik are men's. Knives are today used as often as ever, albeit mass produced stainless-steel blades gradually replace locally made ones [Fig. 4].

16 The authors are grateful to Victoria Soyan Peemot for her help with the identification and description of the symbols. 


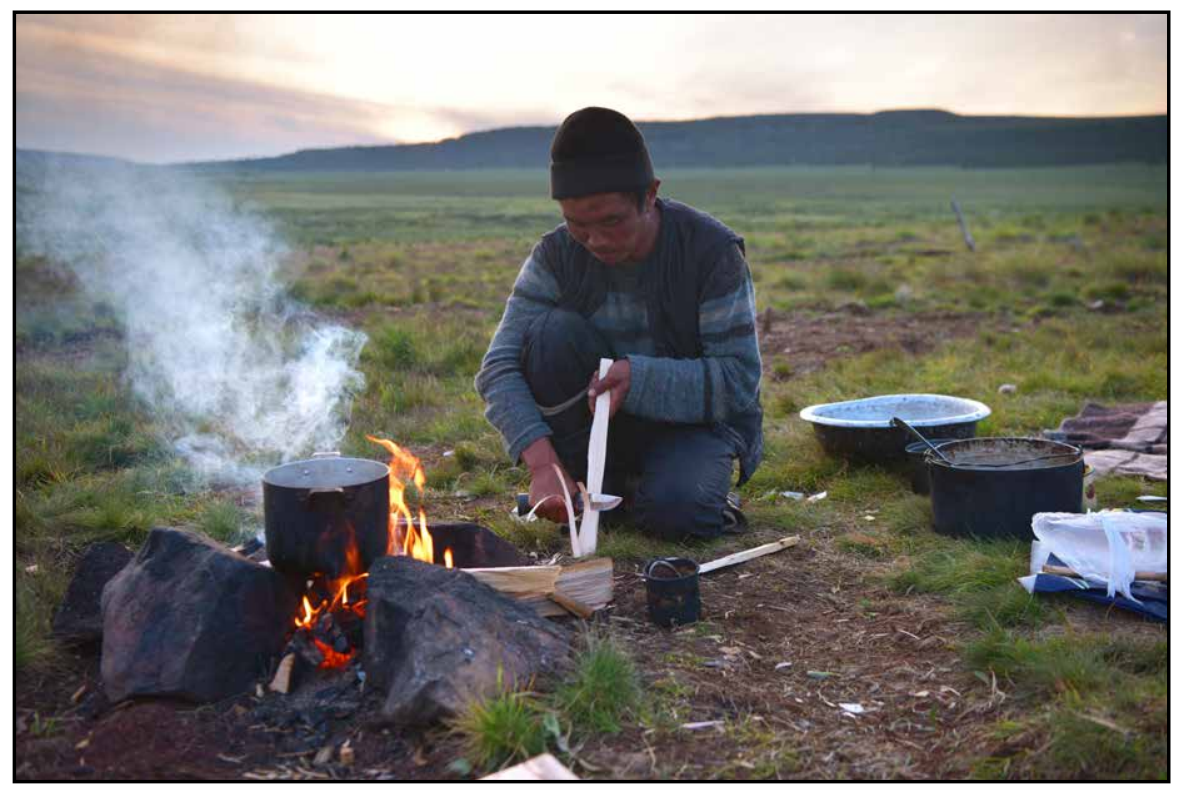

Fig. 4. Reindeer herder uses his modern knife to chip firewood. Todzhinsky kozhuun, 2019 (Photo: Stanislav Krupař).

A portable strike-a-light that was usually carried suspended from the belt or sash is another example of a universally used item. It typically takes the form of a steel frame covered with leather with a bare steel striking face. Strike-a-lights were used to start a fire or to light a pipe. Smoking was and still is common, although nowadays cigarettes are preferred over pipes. The latter are represented by six examples made of wood, with a long and thin stem. Horsehair ropes were used for different purposes, from holding together yurt constructions, through to tethering the animals, and to fastening load to beasts of burden.

Leisure activities are illustrated by two talus (astragalus) bones, probably sheep, that served as game pieces for kazhyk (кажык), and one byzaanchy (бызаанчы). This four-stringed musical instrument is played with a bow that was not collected.

A simple metal ring without any decorations is the only example of personal adornments. The collection is completed by minute items such as two wooden nails, a stone blade, and a dried piece of kurut (курут), or cheese made of leftover protein gained during the distillation of milk spirit araga (арага). The highly nutritious kurut is to the present day popular as a compact source of energy for hunters and travellers.

\section{Conclusion}

The Skalnik's collection forms one of the two cores of the Náprstek Museum's Siberian fund, the other being the collection of František Poledna Vlkovský. ${ }^{17}$ It is significant

17 Bř̀ečka et al. 1991; Halászová 1988. 
not only for its extension, but mostly for its representative documentation of the many aspects of the Tuvan herders' everyday life. The collection was put together with a clear intention and, unlike Poledna Vlkovskýs collection and many other assemblages in the Náprstek Museum, does not contain the production of a souvenir-like or an easily appealing character. It should be admitted that the collection is biased in a different sense - Skalník deliberately sought for 'old' items documenting the 'traditional' way of life; he confirmed in his statement that the money obtained for the items were used for the purchase of comparable goods of modern type or material (e.g., plastic) that were already commonly available. ${ }^{18}$ Even though most of the objects were already out of use, the knowledge of their purpose and employment was still present - and in many cases remains such until the present day.

The assemblage could also be viewed as a representation of objects that could be easily replaced by more convenient alternatives at the time and/or were considered no longer needed. This assumption was correct in some cases (e.g., a strike-a-light was replaced by more convenient matches and lighters) but proved wrong in other cases where the same kind of object is still commonly found and proudly used in Tuvan households in the present day, serving in a sense as identity markers. In any case, Skalnik's collection is a noteworthy case of a systematically created representation of a certain population's everyday life.

Tab. 1. List of objects from Skalnik's collection in the Náprstek Museum.

\begin{tabular}{|c|c|c|c|c|}
\hline Inv. No. & Object & Object in Tuvan & Transcription & Measurements \\
\hline A5201 & ladle & ыяш хымыш & yyash khymysh & $1.53 \mathrm{~cm}$ \\
\hline A5202 & wooden tea mortar & соктааш & soktaash & h. $19 \mathrm{~cm}, \varnothing \max .12 \mathrm{~cm}$ \\
\hline A5203 & stone pestle & бала & bala & $1.21 \mathrm{~cm}$ \\
\hline A5204 & tongs & кыскаш & kyskash & $1.43 \mathrm{~cm}$ \\
\hline A5205 & stirring tool & былгааш & bylgaash & $ø 13 \mathrm{~cm}$ \\
\hline A5206 & whip & кымчы & kymchy & stock $1.60 \mathrm{~cm}$, lash $1.60 \mathrm{~cm}$ \\
\hline A5207 & stirrup & эзеңги & ezengi & h. $18 \mathrm{~cm}, \varnothing 14 \mathrm{~cm}$ \\
\hline A5208 & stirrup & эзеңги & ezengi & h. $17 \mathrm{~cm}, \varnothing 14.5 \mathrm{~cm}$ \\
\hline A5209 & stirrup & эзеңги & ezengi & h. $16 \mathrm{~cm}$, w. $13 \mathrm{~cm}$ \\
\hline A5210 & stirrup & эзеңги & ezengi & h. $14.5 \mathrm{~cm}, \varnothing 13 \mathrm{~cm}$ \\
\hline A5211 & stirrup & эзеңги & ezengi & h. $14.5 \mathrm{~cm}, \varnothing 13 \mathrm{~cm}$ \\
\hline A5212 & stirrup & эзеңги & ezengi & h. $17.5 \mathrm{~cm}, \varnothing 14.5 \mathrm{~cm}$ \\
\hline A5213 & stirrup & эзеңги & ezengi & h. $13.5 \mathrm{~cm}$, w. $12 \mathrm{~cm}$ \\
\hline A5214 & tool for hide softening & эдирээ & ediree & $1.69 .5 \mathrm{~cm}$ \\
\hline A5215 & tool for hide softening & эдирээ & ediree & $1.71 \mathrm{~cm}$ \\
\hline A5216 & smoking pipe & даңза & dangza & $1.52 \mathrm{~cm}$ \\
\hline A5217 & iron hook for meat & илбек & ilbek & $1.50 \mathrm{~cm}$ \\
\hline A5218 & broom & ширбииш & shirbiish & $1.31 \mathrm{~cm}$ \\
\hline A5219 & broom & ширбииш & shirbiish & $1.35 \mathrm{~cm}$ \\
\hline A5220 & tool for hide softening & хыйырак & khyyrak & $1.81 \mathrm{~cm}$, w. $15 \mathrm{~cm}$ \\
\hline A5221 & wooden jug & ыяш хууң & yyash khuung & h. $20 \mathrm{~cm}, \varnothing 13.5 \mathrm{~cm}$ \\
\hline
\end{tabular}

18 Petr Skalník, personal communication. 


\begin{tabular}{|c|c|c|c|c|}
\hline A5222 & wooden vessel & дөмбүң & dömbüng & h. $36 \mathrm{~cm}, \varnothing 19.5 \mathrm{~cm}$ \\
\hline A5223 & wooden jug & ыяш хууң & yyash khuung & h. $23 \mathrm{~cm}, \varnothing 16 \mathrm{~cm}$ \\
\hline A5224 & metal tea mortar & соктааш & soktaash & h. $14 \mathrm{~cm}$ \\
\hline A5225 & whip & кымчы & kymchy & stock $1.49 .5 \mathrm{~cm}$, lash $1.70 \mathrm{~cm}$ \\
\hline A5226 & musical instrument & бызаанчы & byzaanchy & $1.61 \mathrm{~cm}$ \\
\hline A5227 & child's boot & мойтак & moitak & h. $28 \mathrm{~cm}, 1.23 \mathrm{~cm}$ \\
\hline A5228 & child's boot & мойтак & moitak & h. $31 \mathrm{~cm}, 1.22 \mathrm{~cm}$ \\
\hline A5229 & child's boot & мойтак & moitak & h. $30 \mathrm{~cm}, 1.20 \mathrm{~cm}$ \\
\hline A5230 & bit mouthpiece & суглук & sugluk & $1.28 \mathrm{~cm}$ \\
\hline A5231 & smoking pipe & даңза & dangza & $1.28 .5 \mathrm{~cm}$ \\
\hline A5232 & smoking pipe & даңза & dangza & $1.27 \mathrm{~cm}$ \\
\hline A5233 & smoking pipe & даңза & dangza & $1.24 \mathrm{~cm}$ \\
\hline A5234 & scissors & хачы & khachy & $1.25 \mathrm{~cm}$, w. $12 \mathrm{~cm}$ \\
\hline A5235 & leather flask & хойлаарак & khoilaarak & h. $16.5 \mathrm{~cm}$, w. $13 \mathrm{~cm}$ \\
\hline A5236 & smoking pipe & даңза & dangza & $1.20 .5 \mathrm{~cm}$ \\
\hline A5237 & wooden jug & ыяш хууң & yyash khuung & h. $21 \mathrm{~cm}, \varnothing 16.5 \mathrm{~cm}$ \\
\hline A5238 & wooden vessel & дөмбүң & dömbüng & h. $26.5 \mathrm{~cm}, \varnothing 13 \mathrm{~cm}$ \\
\hline A5239 & wooden tea mortar & соктааш & soktaash & h. $19.5 \mathrm{~cm}, \varnothing 19 \mathrm{~cm}$ \\
\hline A5240 & ladle & ыяш хымыш & yyash khymysh & $1.45 \mathrm{~cm}$ \\
\hline A5241 & horsehair rope & чеп баг & chep bag & 1. $120 \mathrm{~cm}$ \\
\hline A5242 & grain mortar & соктааш & soktaash & h. $47 \mathrm{~cm}, \varnothing 21 \mathrm{~cm}$ \\
\hline A5243 & stoneware vessel & дөмбүң & dömbüng & h. $25 \mathrm{~cm}, \varnothing 19 \mathrm{~cm}$ \\
\hline A5244 & bit mouthpiece & суглук & sugluk & 1. ca. $120 \mathrm{~cm}$ \\
\hline A5245 & bowl & аяк & ayak & h. $6 \mathrm{~cm}, \varnothing 12 \mathrm{~cm}$ \\
\hline A5246 & bowl & аяк & ayak & h. $6 \mathrm{~cm}, \varnothing 15 \mathrm{~cm}$ \\
\hline A5247 & bowl & аяк & ayak & h. $5 \mathrm{~cm}, \varnothing 23 \mathrm{~cm}$ \\
\hline A5248 & dried cheese & курут & kurut & w. $4 \mathrm{~cm}, 1.3 .5 \mathrm{~cm}$ \\
\hline A5249 & percussion lock & тонак & tonak & $1.8 \mathrm{~cm}$ \\
\hline A5250 & leather strap & баг & bag & $1.86 \mathrm{~cm}$ \\
\hline A5251 & spindle & ээргииш & eergiish & $1.23 \mathrm{~cm}, \varnothing 7 \mathrm{~cm}$ \\
\hline A5252 & spindle & ээргииш & eergiish & $1.27 \mathrm{~cm}, \varnothing 7 \mathrm{~cm}$ \\
\hline A5253 & cuffs & дужак & duzhak & $1.26 \mathrm{~cm}$ \\
\hline A5254 & stirring tool (fragment) & калгак & kalgak & $\varnothing 13 \mathrm{~cm}$ \\
\hline A5255 & wooden jug & ыяш хууң & yyash khuung & h. $22 \mathrm{~cm}, \varnothing 15 \mathrm{~cm}$ \\
\hline A5256 & wooden jug & ыяш хуун & yyash khuung & h. $24 \mathrm{~cm}, \varnothing 20.5 \mathrm{~cm}$ \\
\hline A5257 & wooden vessel (small) & сыгыртаa & sygyrtaa & h. $15 \mathrm{~cm}, \varnothing 14 \mathrm{~cm}$ \\
\hline A5258 & spade blade & хүүрек & khüürek & $1.18 \mathrm{~cm}$ \\
\hline A5259 & spade blade & хүүрек & khüürek & $1.17 \mathrm{~cm}$ \\
\hline A5260 & shoe last & кадыг идик хеви & kadyg idik khevi & $1.29 .5 \mathrm{~cm}$, w. $9 \mathrm{~cm}$ \\
\hline A5261 & leather sack & шоодай & shooday & $1.52 \mathrm{~cm}$, w. $22 \mathrm{~cm}$ \\
\hline A5262 & trough & деспи & despi & $1.41 \mathrm{~cm}, \mathrm{w} .21 .5 \mathrm{~cm}$ \\
\hline A5263 & calf muzzle & халбагайты & khalbagayty & 1. $15.5 \mathrm{~cm}, \mathrm{~h} .13 \mathrm{~cm}$ \\
\hline A5264 & calf muzzle & халбагайты & khalbagayty & $1.11 \mathrm{~cm}, \mathrm{~h} .12 \mathrm{~cm}$ \\
\hline A5265 & sickle & кадыыр & kadyyr & $1.41 \mathrm{~cm}$ \\
\hline A5266 & decorative stencil & хеп & khep & $1.25 \mathrm{~cm}$, w. $15 \mathrm{~cm}$ \\
\hline
\end{tabular}




\begin{tabular}{|c|c|c|c|c|}
\hline A5267 & chisel & шүҮче & shüüche & $1.21 \mathrm{~cm}$ \\
\hline A5268 & pestle & бала & bala & $1.90 \mathrm{~cm}$ \\
\hline A5269 & trough & деспи & despi & $1.37 .5 \mathrm{~cm}$, w. $13.5 \mathrm{~cm}$ \\
\hline A5270 & leather sack & шоодай & shooday & $1.62 \mathrm{~cm}$, w. $34 \mathrm{~cm}$ \\
\hline A5271 & trough & деспи & despi & 1. $60.5 \mathrm{~cm}$, w. $28 \mathrm{~cm}$ \\
\hline A5272 & trough & челбиир деспи & chelbiir despi & $1.65 \mathrm{~cm}$, w. $30 \mathrm{~cm}$ \\
\hline A5273 & horsehair rope & чеп баг & chep bag & 1. ca. $250 \mathrm{~cm}$ \\
\hline A5274 & saddle bag & таалың & taalyng & 1. ca. $125 \mathrm{~cm}$, w. $33 \mathrm{~cm}$ \\
\hline A5275 & grain mortar & соктааш & soktaash & h. $48 \mathrm{~cm}, \varnothing 20 \mathrm{~cm}$ \\
\hline A5276 & knife and sheath & бижек & bizhek & knife $1.35 \mathrm{~cm}$, sheath $1.30 \mathrm{~cm}$ \\
\hline A5277 & gunpowder pouch & чыгак & chygak & $1.17 .5 \mathrm{~cm}$ \\
\hline A5278 & sheath & хын & khyn & $1.21 .5 \mathrm{~cm}$ \\
\hline A5279 & horseshoe & дага & daga & $\varnothing 10.5 \mathrm{~cm}$ \\
\hline A5280 & lock & шооча & shoocha & $1.5 \mathrm{~cm}$, w. $4.5 \mathrm{~cm}$ \\
\hline A5281 & awl & шивегей & shivegey & $1.9 \mathrm{~cm}, \varnothing 2 \mathrm{~cm}$ \\
\hline A5282 & thimble & чүскүк & chüskük & $\varnothing 2 \mathrm{~cm}, 1.2 .5 \mathrm{~cm}$ \\
\hline A5283 & strike-a-light & оттук & ottuk & $1.9 \mathrm{~cm}$, w. $6 \mathrm{~cm}$ \\
\hline A5284 & lock & шооча & shoocha & $1.4 .5 \mathrm{~cm}$, w. $5.5 \mathrm{~cm}$ \\
\hline A5285ab & lock and key & шооча, дүлгүүр & shoocha, dülgüür & $1.7 \mathrm{~cm}$, w. $6 \mathrm{~cm}$ \\
\hline A5286 & bone game piece & кажык & kazhyk & $1.3 \mathrm{~cm}$ \\
\hline A5287 & bone game piece & кажык & kazhyk & $1.3 \mathrm{~cm}$ \\
\hline A5288 & button & бельдир & beldir & $\varnothing 1.8 \mathrm{~cm}$ \\
\hline A5289 & button & бельдир & beldir & $ø 2.3 \mathrm{~cm}$ \\
\hline A5290 & button & тарылга & tarylga & $\varnothing 5.3 \mathrm{~cm}$ \\
\hline A5291 & button & тарылга & tarylga & $ø 4 \mathrm{~cm}$ \\
\hline A5292 & button & тарылга & tarylga & $1.6 \mathrm{~cm}, \mathrm{w} .4 \mathrm{~cm}$ \\
\hline A5293 & stone blade & даш бис & dash bis & $1.4 \mathrm{~cm}$, w. $3 \mathrm{~cm}$ \\
\hline A5294 & libation spoon & тос карак & tos karak & $1.36 \mathrm{~cm}$ \\
\hline A5295ab & horseshoe & дага & daga & $ø 10 \mathrm{~cm}$ \\
\hline A5296 & felt sample & кидис & kidis & $1.31 \mathrm{~cm}$ \\
\hline A5297 & chest & аптара & aptara & $1.63 .5 \mathrm{~cm}$, w. $30 \mathrm{~cm}$, h. $32 \mathrm{~cm}$ \\
\hline A5298 & felt sack & шоодай & shooday & $1.50 \mathrm{~cm}$ \\
\hline A5299 & felt rug (fragment) & ширтэк & shirtek & $1.75 \mathrm{~cm}$ \\
\hline A5300 & leather sack & шоодай & shooday & $1.60 \mathrm{~cm}$, w. $50 \mathrm{~cm}$ \\
\hline A5451ab & chest & аптара & \begin{tabular}{|l|} 
aptara \\
\end{tabular} & $1.66 \mathrm{~cm}$, w. $31 \mathrm{~cm}$, h. $41 \mathrm{~cm}$ \\
\hline A5452 & saddle & эзер & ezer & $1.44 \mathrm{~cm}$, w. $32 \mathrm{~cm}$ \\
\hline A5453 & tripod for cauldron & ожук & ozhuk & h. $32 \mathrm{~cm}, \varnothing 41 \mathrm{~cm}$ \\
\hline A5454 & tripod for cauldron & ожук & \begin{tabular}{|l|} 
ozhuk \\
\end{tabular} & h. $25 \mathrm{~cm}, \varnothing 39 \mathrm{~cm}$ \\
\hline A5455 & wooden nail & шопту & shoptu & $1.3 .5 \mathrm{~cm}$ \\
\hline A5456 & wooden nail & шопту & shoptu & $1.4 \mathrm{~cm}$ \\
\hline A5457 & ring & чүстүк & chüstük & $ø 2 \mathrm{~cm}$ \\
\hline A5458 & smoking pipe (fragment) & даңза & dangza & $1.7 \mathrm{~cm}$ \\
\hline
\end{tabular}

Note: Tuvan names of the objects are mostly based on Skalnik's evidence cards with some corrections in cases where the names were not specific or precise, could not be verified or were missing. The adjustments were made in cooperation with native speakers. Skalnik himself did not speak Tuvan and thus his terminology was based on field notes and dictionaries. Note that for some objects (е.g., соктааш and согааш for a mortar, or халбагайты and калбаңнааш for a calf muzzle) synonymous terms are in use. 


\section{Acknowledgements}

The authors would like to express their gratitude to PhDr. Petr Skalnik, CSc., Victoria Soyan Peemot from the University of Helsinki, and all their Tuvan friends for their kind and patient cooperation.

\section{Literature:}

Asijské kultury = Asijské kultury ve sbírkách Náprstkova muzea. (1981). Praha: Národní muzeum.

Břečka, J., Klápštová, K., Halászová, V., Peigrová, J., Trojánek, A. and Neužil, O. (2001). František Poledna Vlkovský a Čukčové. Brno: Moravské zemské muzeum.

Даржа, В. (2009). Традиционные мужские занятиа Тувинцев. Кызыл: Тувинское книжное издательство.

Jungová, G. (2020). Doma na Sibiři/ At Home in Siberia. Praha: Národní muzeum.

Halászová, V. (1988). Ethnographical collection from North-Eastern Siberia in the Náprstek Museum. Annals of the Náprstek Museum, 15, pp. 9-46.

Левин, М. and Потапов, Л. (1956). Народы Сибири. Москва - Ленинград: Издательство Академии наук СССР.

Vainshtein, S. (2009). Nomads of South Siberia. Edited with an introduction by Caroline Humphrey. Cambridge: Cambridge University Press. 


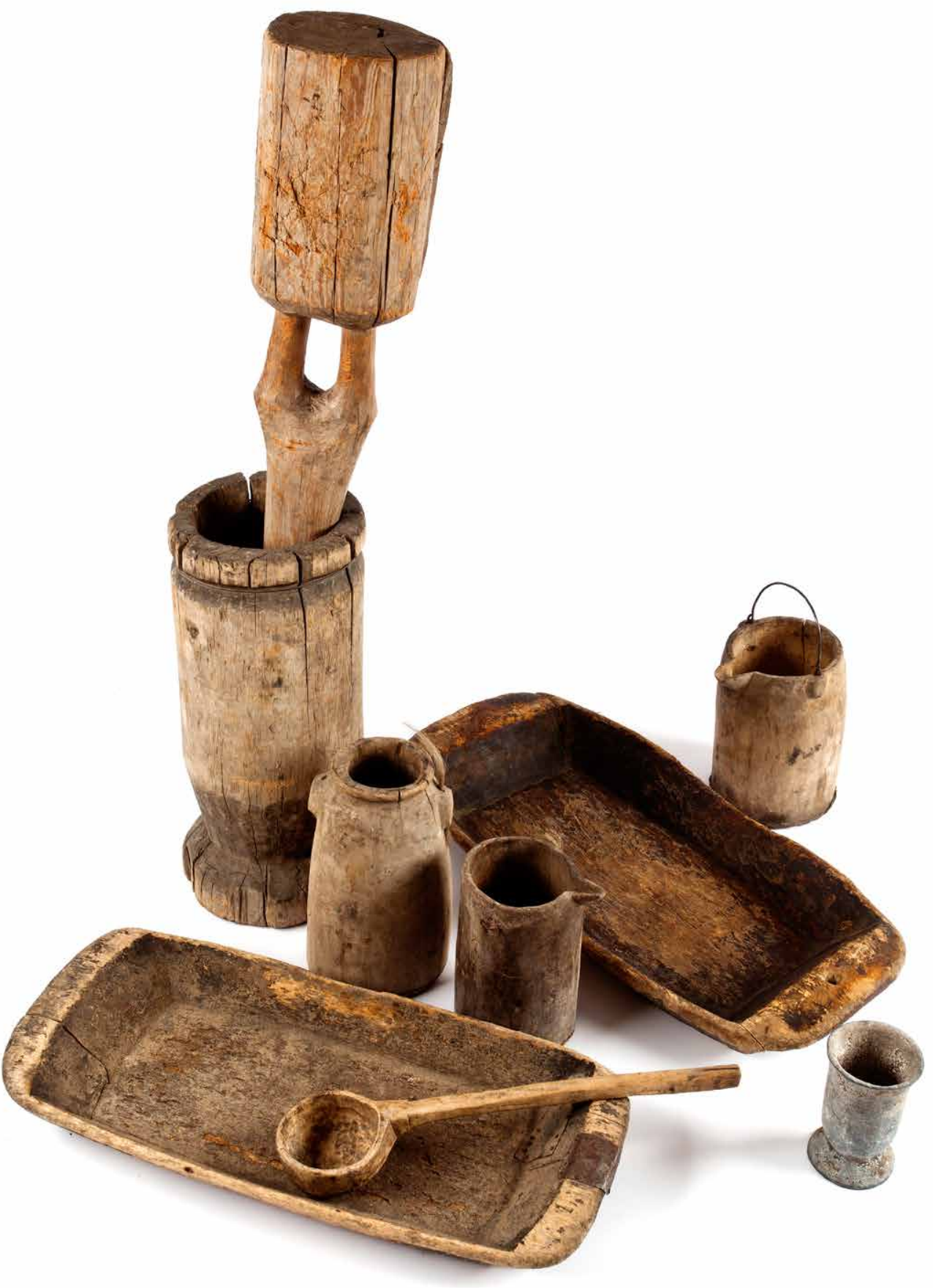

Pl. 1. Kitchenware, vessels, and tools for storing and processing food: A5242, A5268, A5221, A5224, A5238, A5240, A5255, A5271, A5272 (Photo: Jiří Vaněk). 

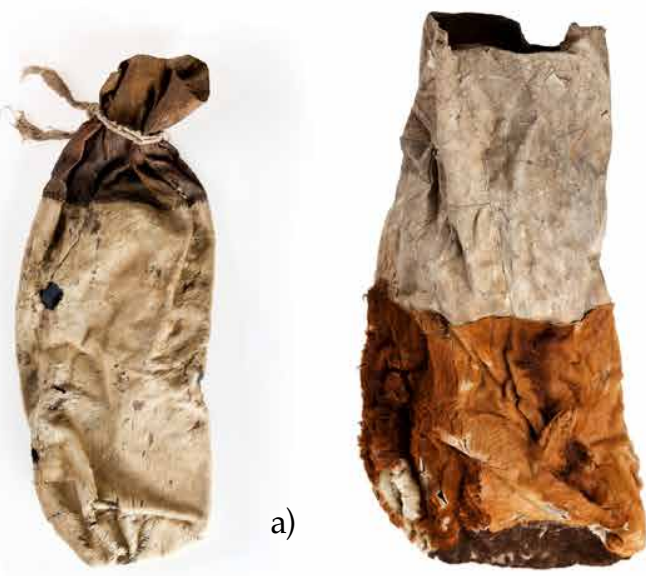

d)

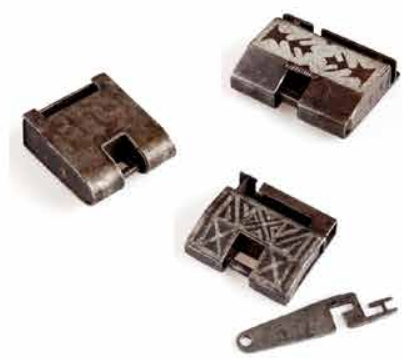

a)

e)
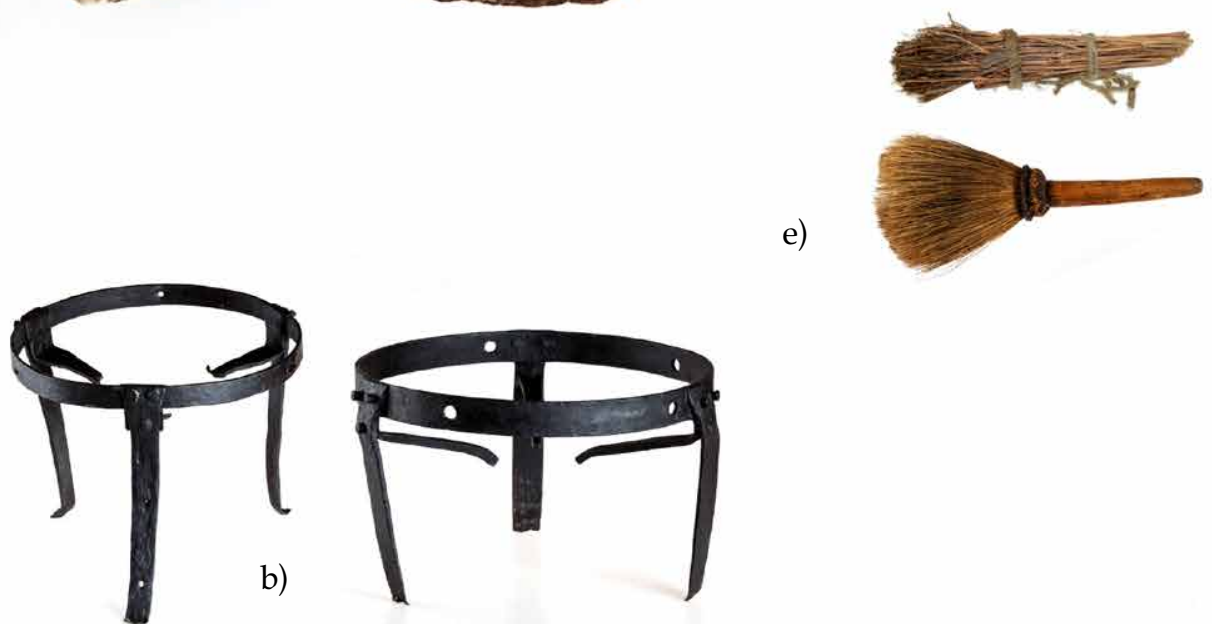

f)
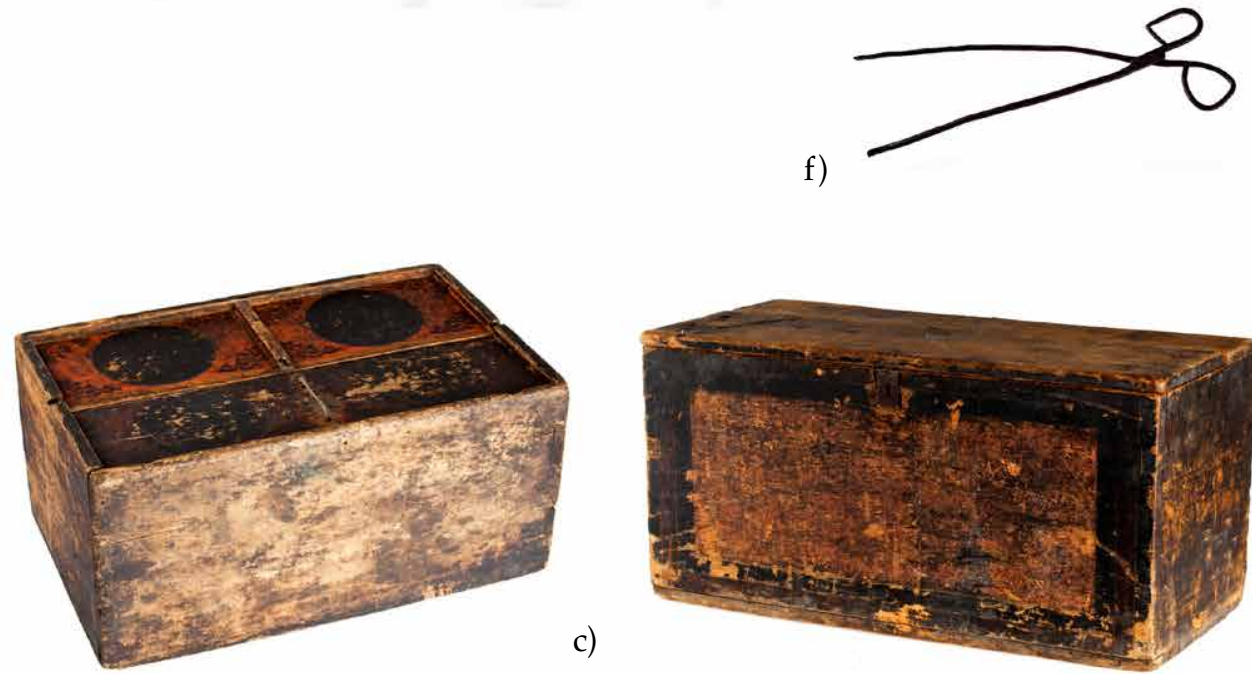

Pl. 2. Household needs: a) A5261, A5270; b) A5453, A5454; c) A5451, A5297; d) A5284, A5280, A5285ab; e) A5218, A5219; f) A5204 (Photo: Jiří Vaněk). 

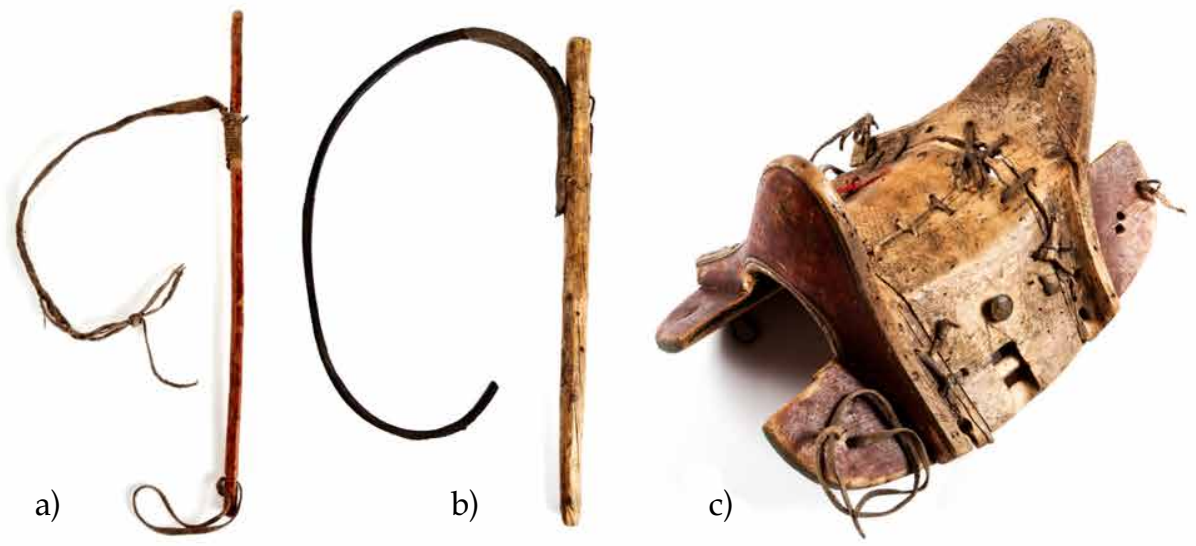

d)

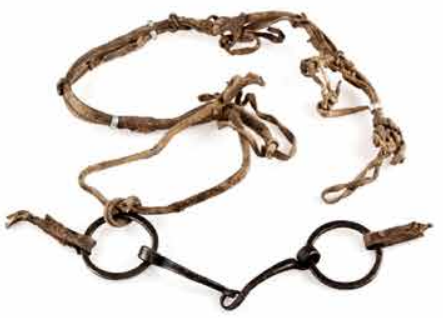

e)

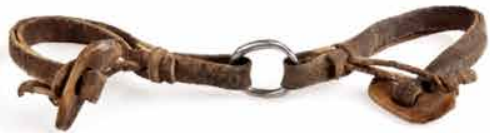

f)

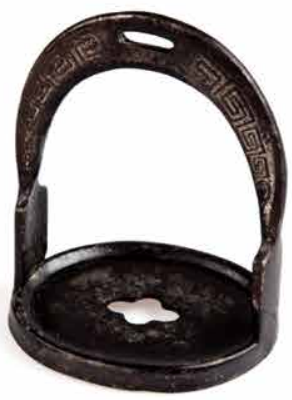

g)
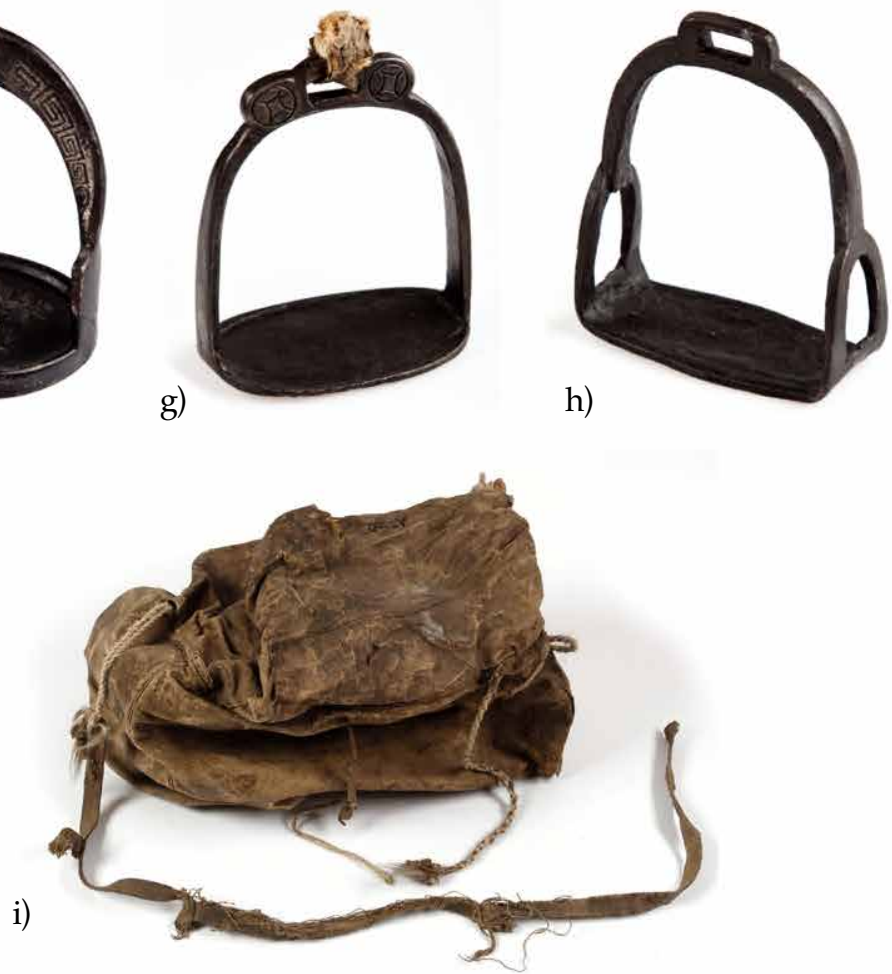

Pl. 3. Selection of equestrian needs: a) A506; b) A5225; c) A5452; d) A5244; e) A5253; f) A5207; g) A5211; h) A5213; i) A5300 (Photo: Jiří Vaněk). 


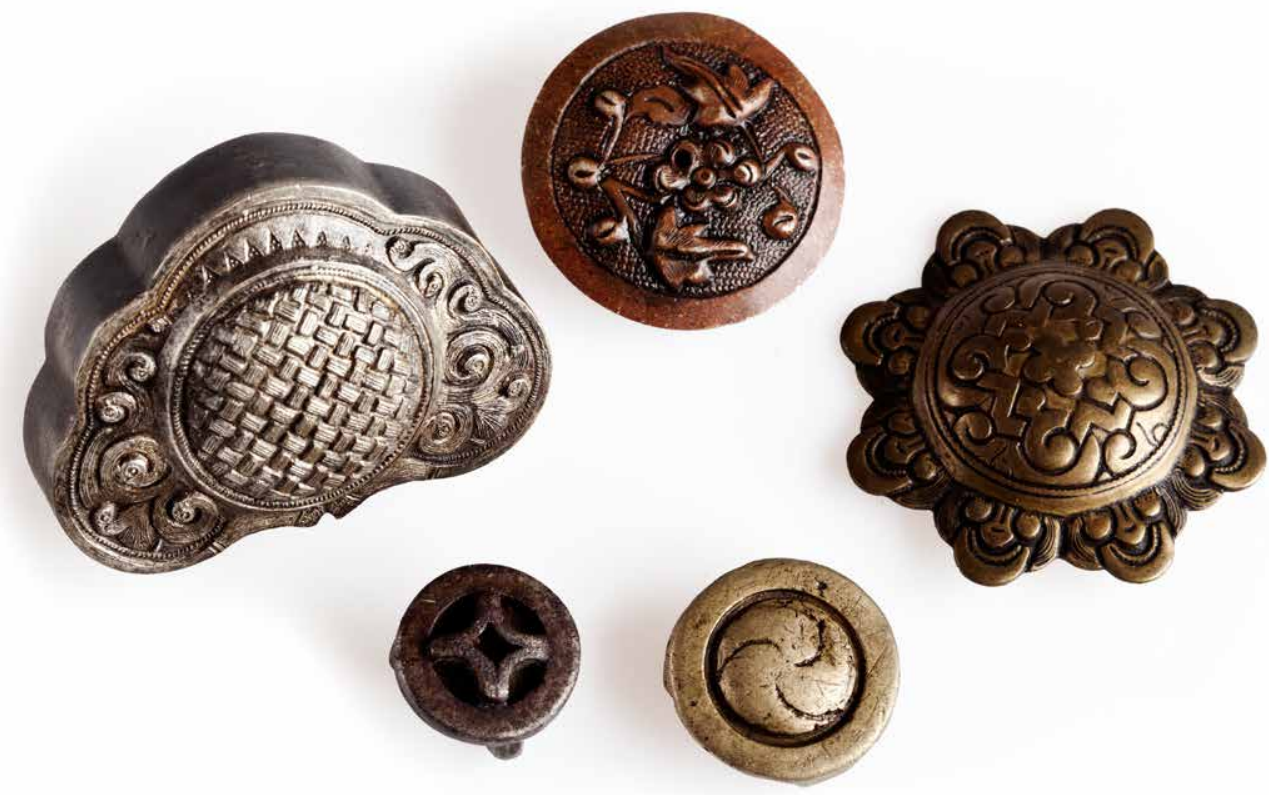

P1. 4. Horse brasses, or buttons decorating the horse harness: A5292, A5291, A5290, A5288, A5289 (Photo: Jiř́ Vaněk).
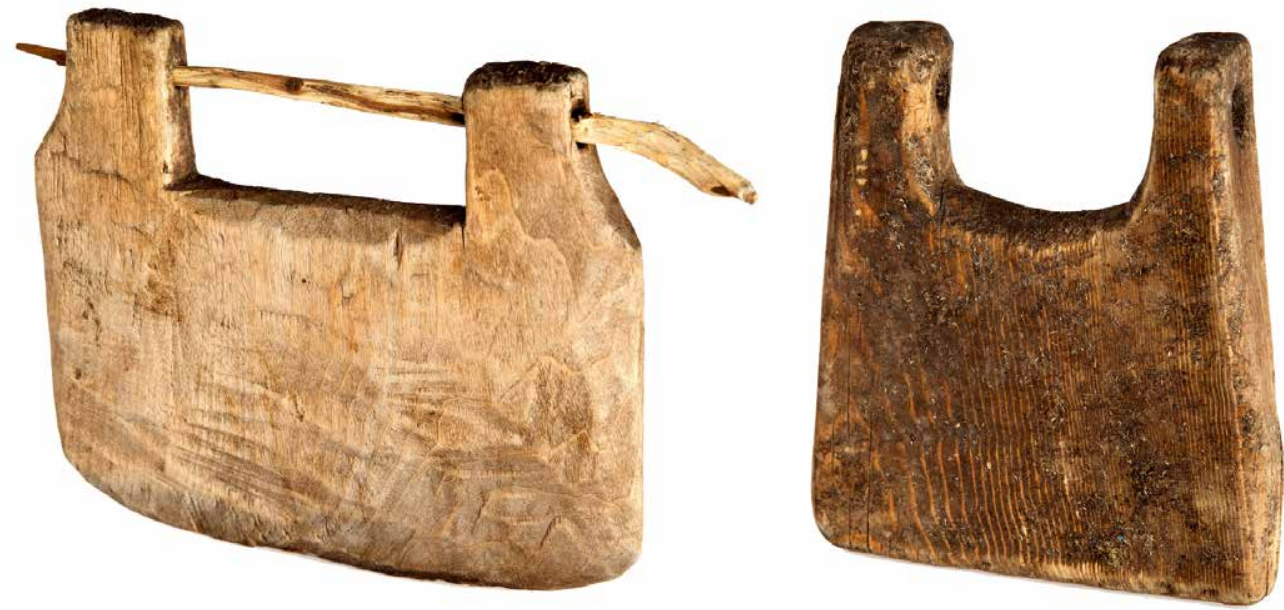

Pl. 5. Anti-suckling muzzles for calves: A5263, A5264 (Photo: Jiř́ Vaněk). 


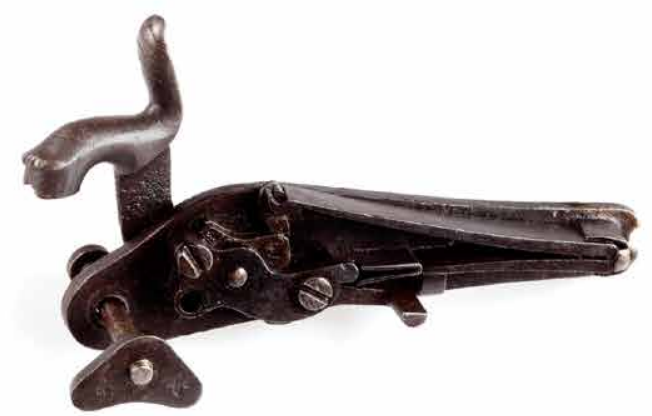

a)

b)
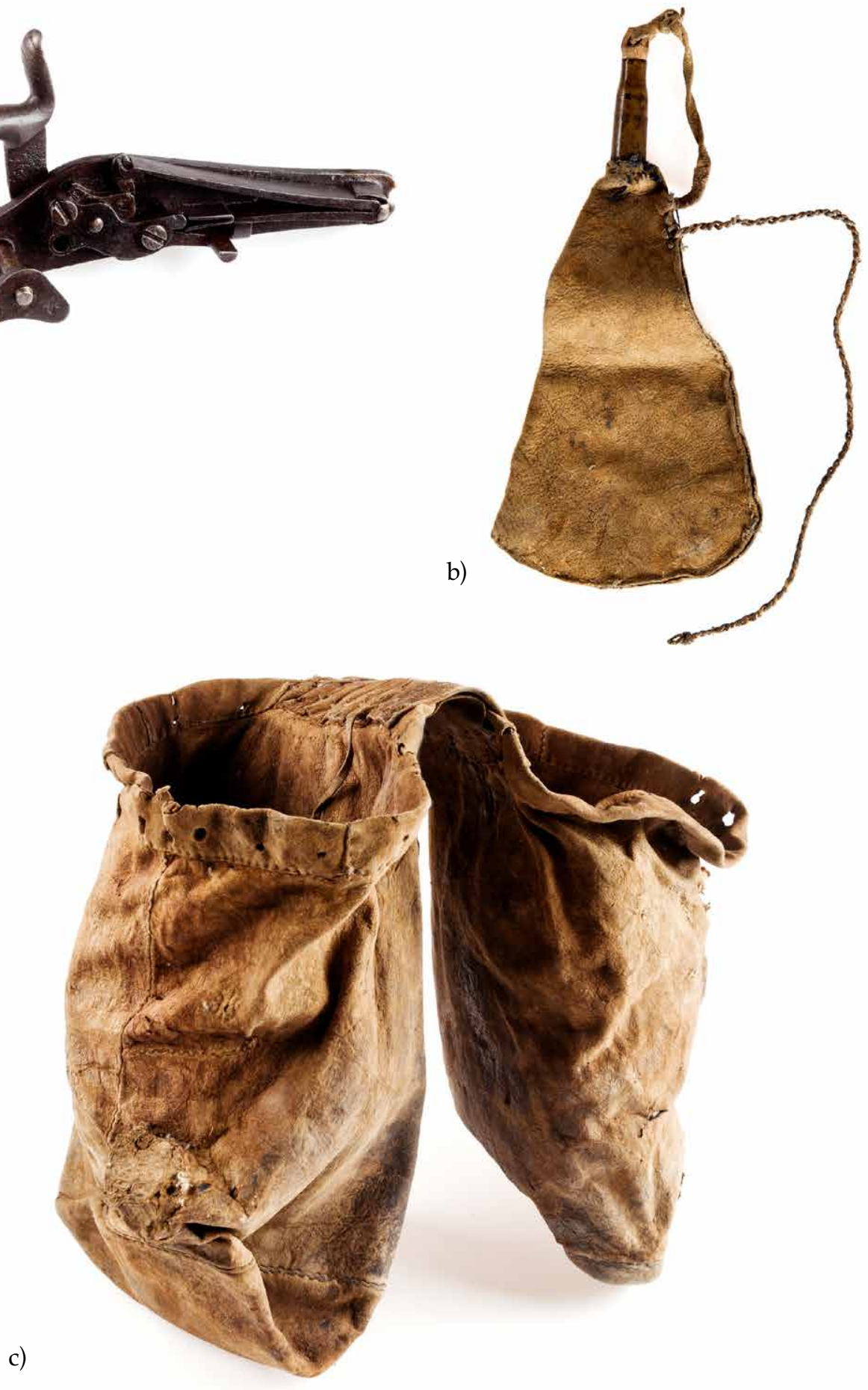

Pl. 6. Hunting needs: a) A5249; b) A5277; c) A5274

(Photo: Jiř́ Vaněk). 


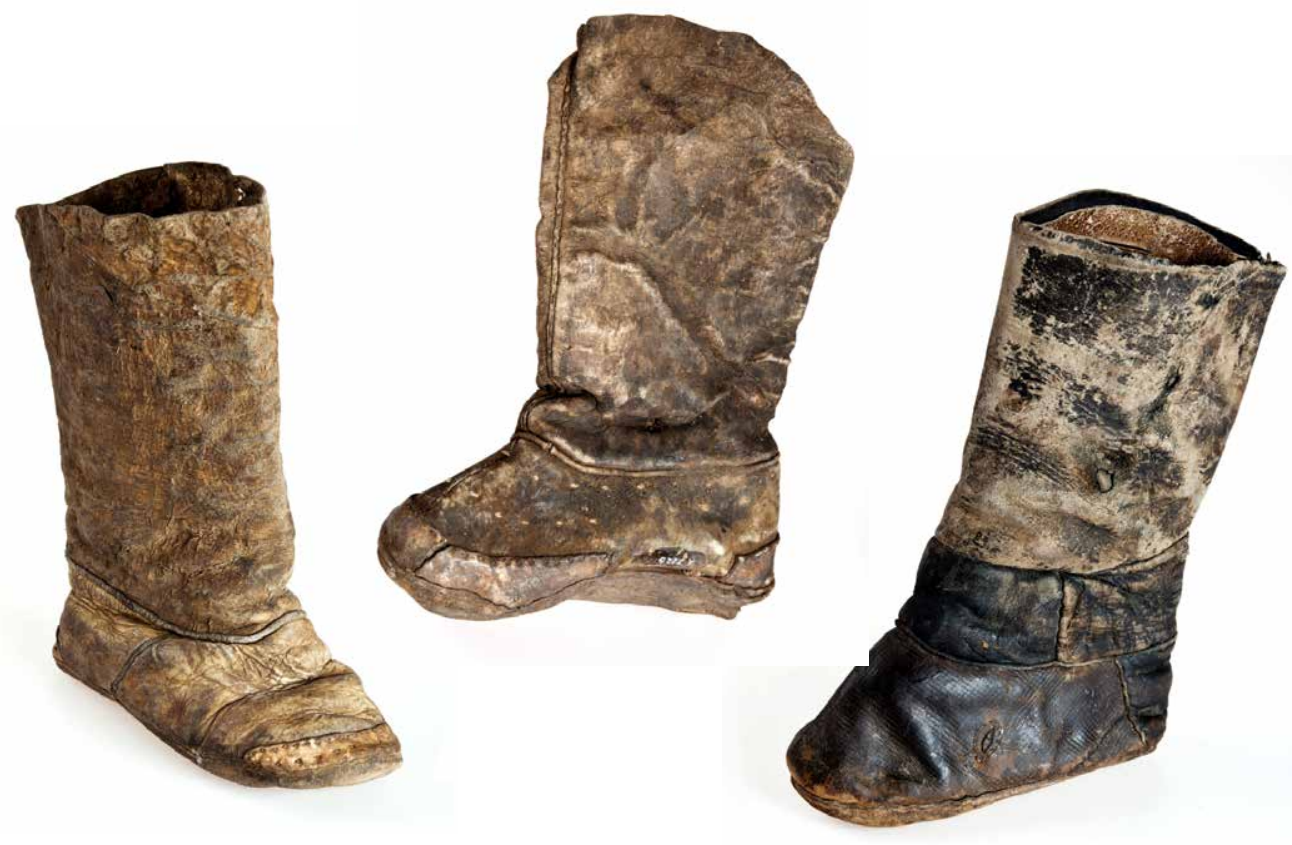

P1. 7. Leather boots: A5227, A5228, A5229

(Photo: Jiří Vaněk).

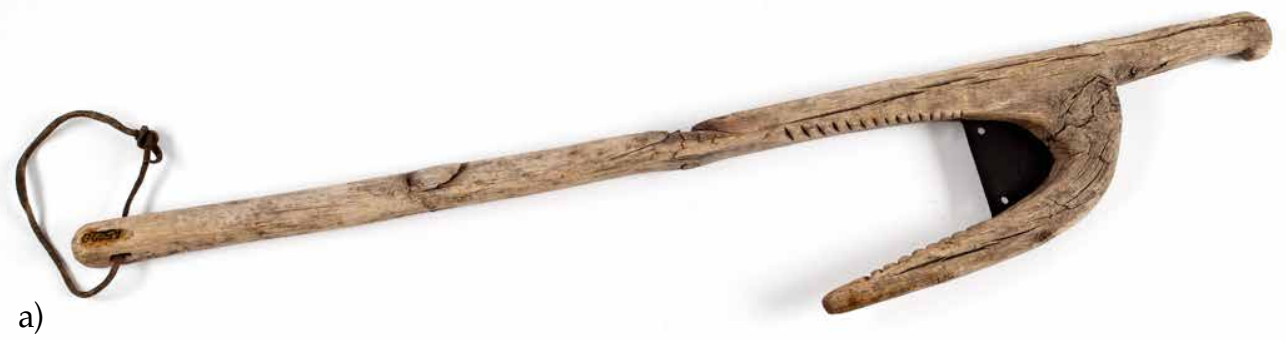

b)

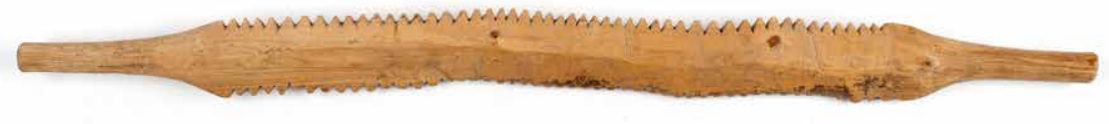

c)

Pl. 8. Hide softening tools: a) A5220; b) A5214; c) A5215

(Photo: Jiř́ Vaněk). 


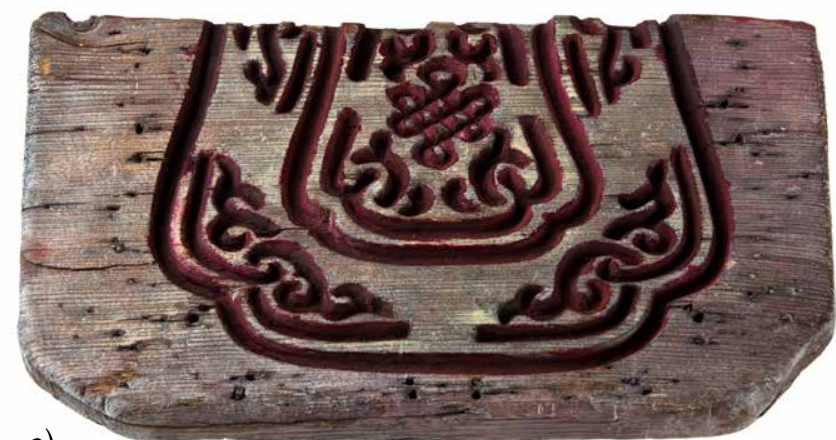

a)

b)

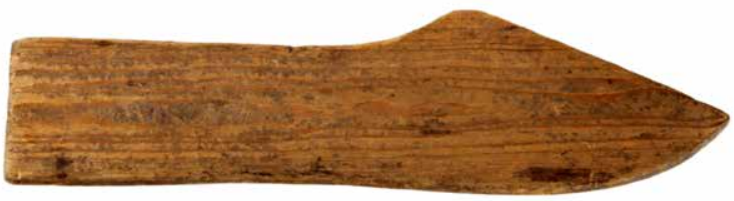

c)

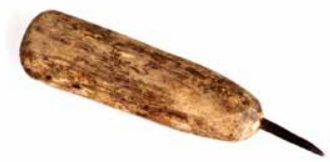

d)

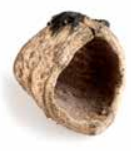

Pl. 9. Needs for leatherwork: a) A5266; b) A5260; c) A5281; d) A5282

(Photo: Jiří Vaněk).
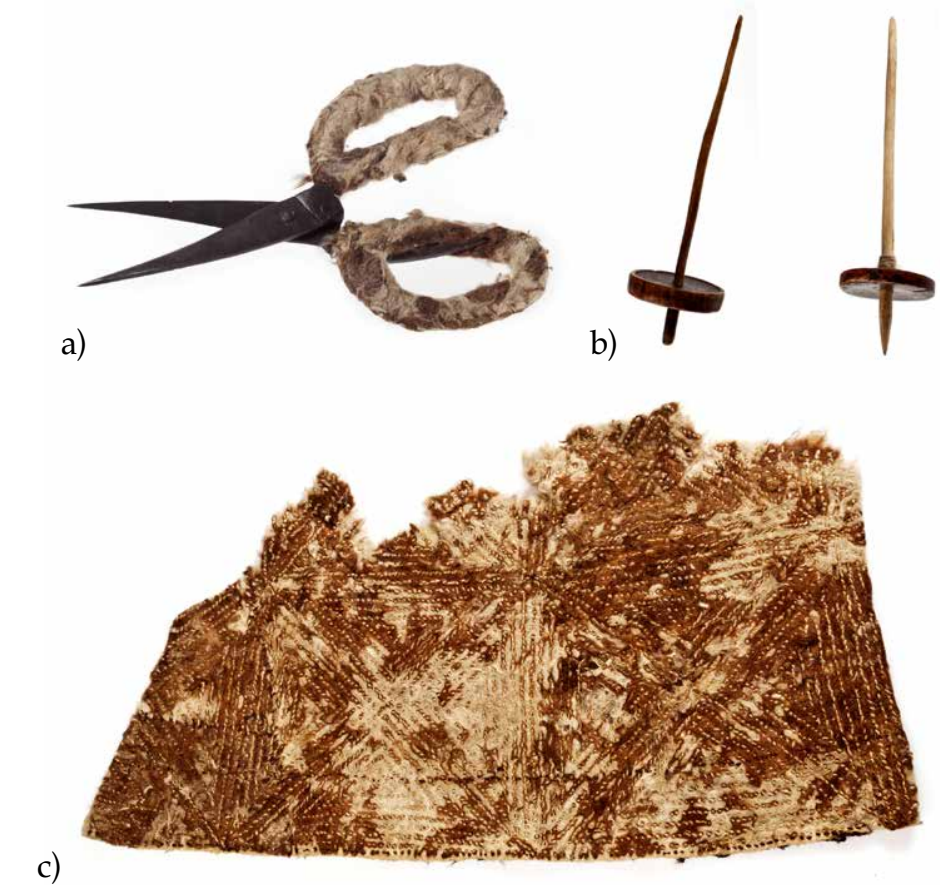

Pl. 10. Needs for processing wool: a) A5234; b) A5251, A5252; and a sample of wool: c) A5299 (Photo: Jiří Vaněk). 

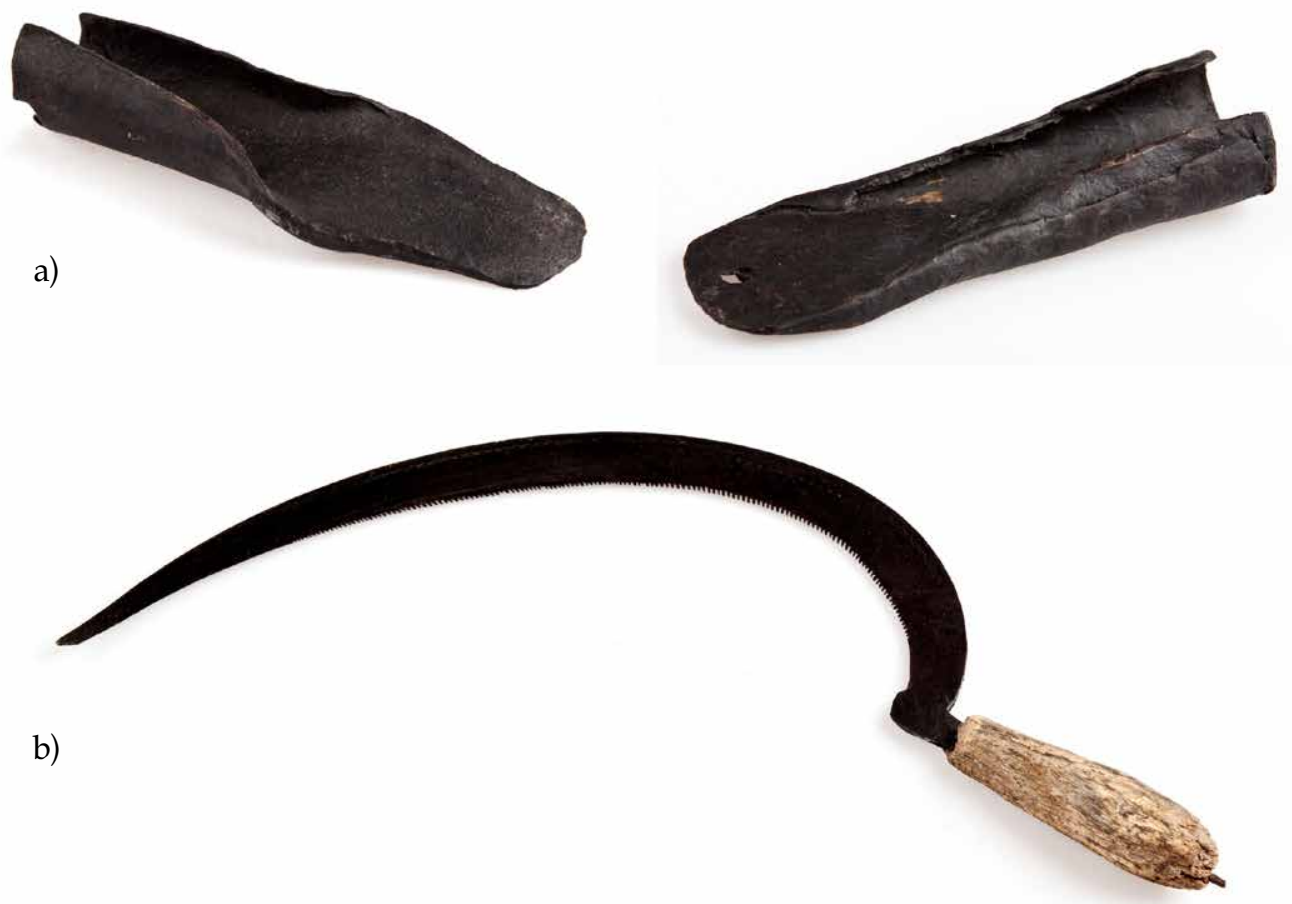

P1. 11. Needs for cultivating land: a) A5258, A5259; b) A5265

(Photo: Jiří Vaněk).

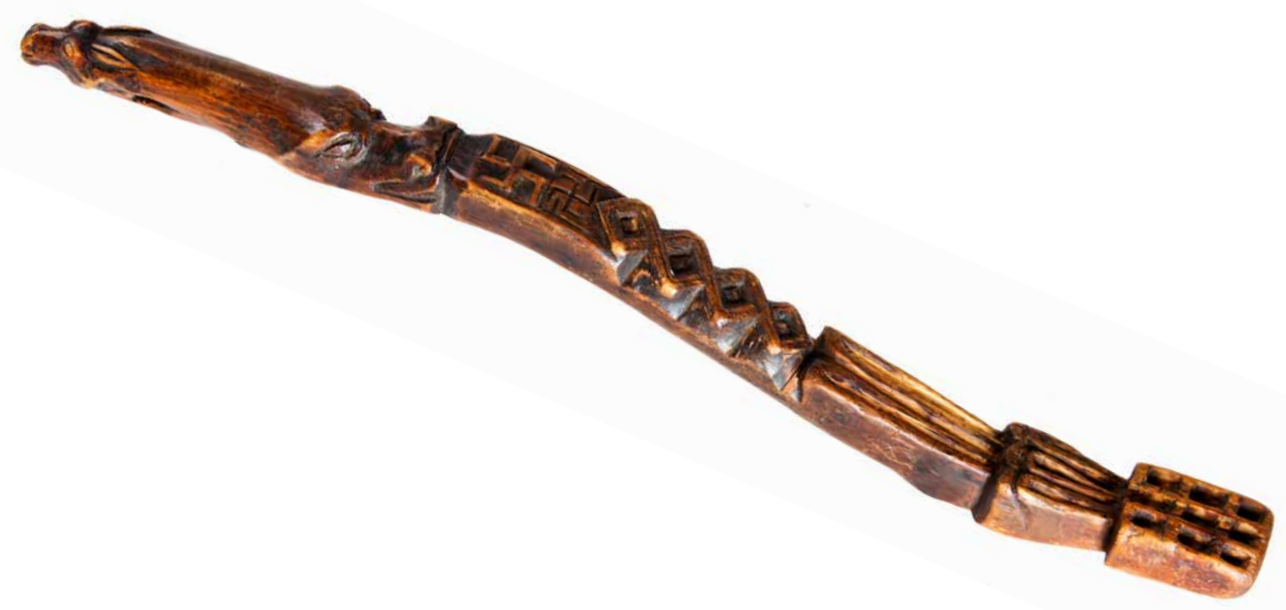

Pl. 12. Ceremonial spoon tos karak, A5294

(Photo: Jiří Vaněk). 


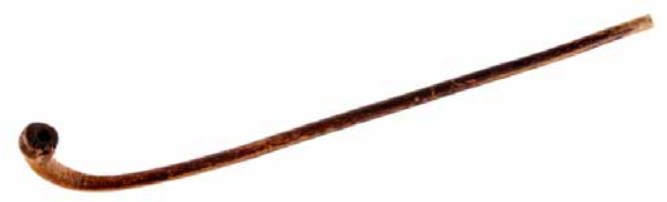

a)

b)
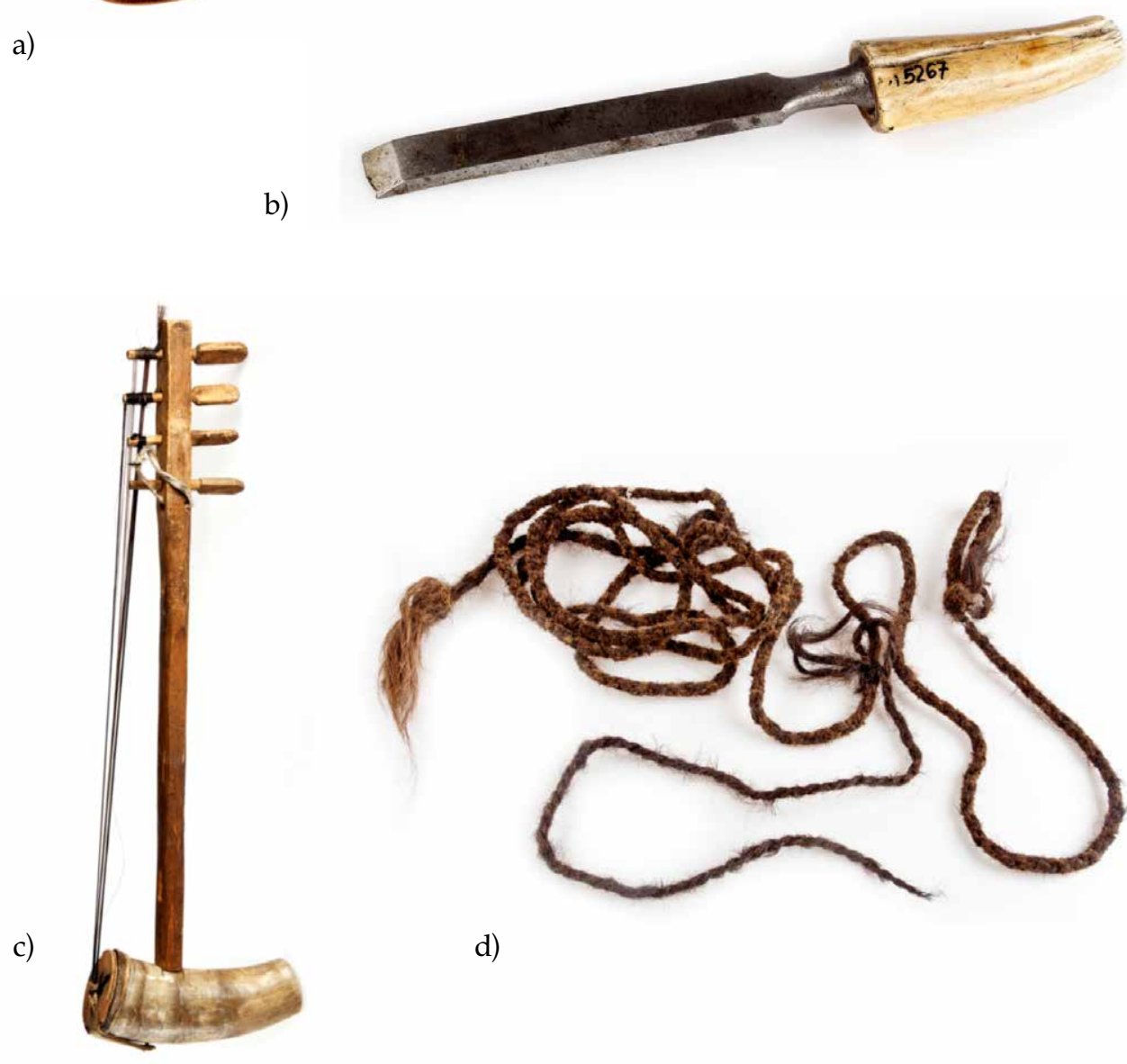

d)

e)
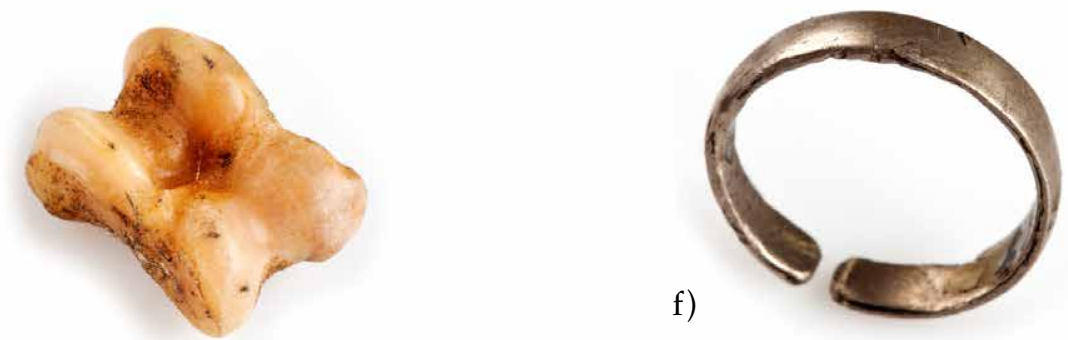

Pl. 13. Selected miscellaneous objects from Tuva: a) A5216; b) A5267; c) A5226; d) A5273; e) A5286; f) A5457 (Photo: Jiří Vaněk). 
a)

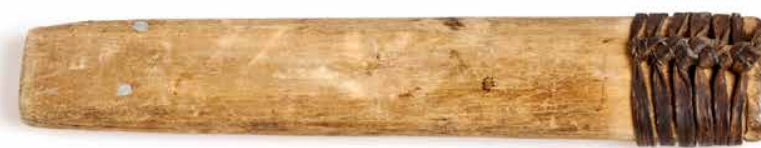

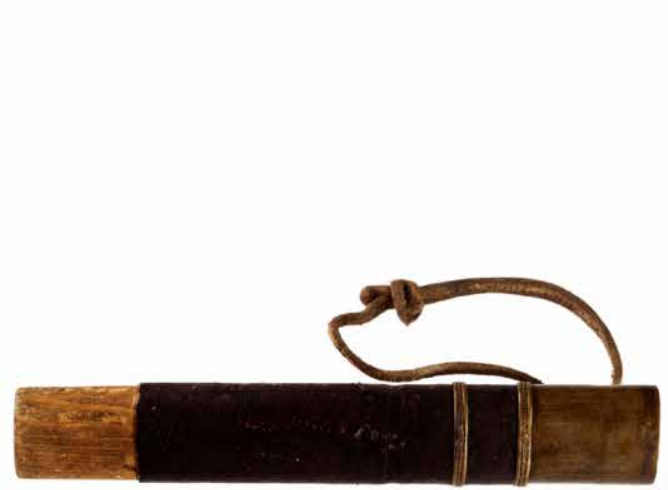

b)

Pl. 14. Universally used items: a) A5276ab; b) A5278; c) A5283

(Photo: Jiří Vaněk).

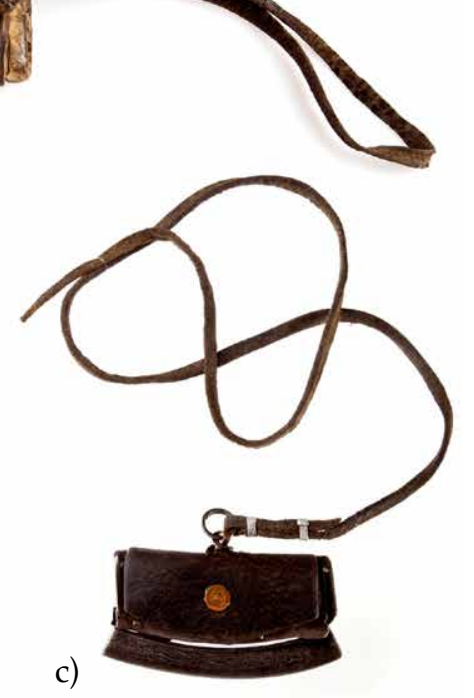

c)

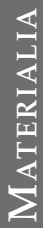

